\title{
Article/Artigo
}

\section{Epidemiological factors related to the transmission risk of Trypanosoma cruzi in a Quilombola community, State of Mato Grosso do Sul, Brazil}

\author{
Aspectos epidemiológicos relacionados ao risco de transmissão de Trypanosoma cruzi \\ em comunidade Quilombola, Estado de Mato Grosso do Sul, Brasil
}

\author{
Marlon Cezar Cominetti ${ }^{1}$, Renato Andreotti ${ }^{2}$, Elisa Teruya Oshiro ${ }^{3}$ and Maria Elizabeth Moraes Cavalheiros Dorval ${ }^{3}$
}

\begin{abstract}
Introduction: This work was an epidemiological investigation of the risk of Trypanosoma cruzi transmission in the rural Quilombola community of Furnas do Dionízio, State of Mato Grosso do Sul, Brazil. Methods: Of the 71 animals examined, seven were captured (two opossums, Didelphis albiventris; four rats, Rattus rattus; and one nine-banded armadillo, Dasypus novemcinctus) and 64 were domestic (one canine, Canis familiaris; five pigs, Sus scrofa; two bovines, Bos taurus; five caprines, Capra sp.; and 51 ovines, Ovis aries). Parasitological tests were performed to detect parasites in the blood and to identify the morphology of flagellates. These methods included fresh examinations, buffy coat tests and blood cultures. Molecular analysis of DNA for identification of trypanosomatids was performed by polymerase chain reaction (PCR) with primers S35 and S36. Results: The parasitological tests showed flagellates in an opossum and two cattle. The molecular tests showed DNA from T. cruzi in an opossum and a pig. Triatoma sordida was the only triatomine species found in the community, and it colonized households (four specimens) and the surrounding areas (124 specimens). Twentythree specimens tested positive for flagellates, which were subsequently identified as $T$. cruzi by PCR. Conclusions: Data analysis demonstrated that T. cruzi has a peridomestic life cycle that involves both domestic and wild mammals.
\end{abstract}

Keywords: Tripanosomatides. Triatoma sordida. Triatomines. Synanthropic animals. PCR.

\section{RESUMO}

Introdução: Este trabalho foi uma investigação epidemiológica do risco de transmissão de Trypanosoma cruzi na comunidade rural Quilombola de Furnas do Dionízio, Estado de Mato Grosso do Sul. Métodos: Dos 71 animais examinados, sete foram capturados (dois gambás, Didelphis albiventris; quatro ratos, Rattus rattus; e um tatu, Dasypus novemcinctus) e 64 eram domésticos (um canídeo, Canis familiaris; cinco suínos, Sus scrofa; dois bovinos, Bos taurus; cinco caprinos, Capra sp; e 51 ovinos, Ovis aries). Exames parasitológicos foram realizados para detectar parasitas no sangue e para identificar a morfologia dos flagelados. Estes métodos incluíram exame a fresco, exame do creme leucocitário e hemocultura. A análise molecular de DNA para identificação de tripanossomatídeos encontrados foi feita pela reação em cadeia da polimerase (PCR) com os primers S35 e S36. Resultados: Os exames parasitológicos mostraram flagelados em um gambá e nos dois bovinos. Os testes moleculares mostraram a presença do DNA de T. cruzi em um gambá e um suíno. Triatoma sordida foi a única espécie de triatomíneo encontrada na comunidade colonizando domicílio (quatro espécimes) e peridomicílio (124 espécimes). Vinte e três amostras foram positivas para flagelados e identificados como T. cruzi pela PCR. Conclusões: A análise dos dados aponta para o ciclo peridoméstico do parasita e envolve tanto animais domésticos como selvagens.

Palavras-chaves: Tripanosomatideos. Triatoma sordida. Triatomíneos. Animais sinantrópicos. PCR.

1. Programa de Pós Graduação em Doenças Infecciosas e Parasitárias, Faculdade de Medicina, Universidade Federal de Mato Grosso do Sul, Campo Grande, MS. 2. Sanidade Animal, Empresa Brasileira de Pesquisa Agropecuária Gado de Corte, Campo Grande, MS. 3. Laboratório de Parasitologia Humana, Universidade Federal de Mato Grosso do Sul, Campo Grande, MS.

Address to: Dr. Renato Andreotti. Lab. Biologia Molecular/Sanidade Animal/EMBRAPA Gado de Corte. BR 262, km 04, Caixa Postal 15479, 79002-970 Campo Grande, MS, Brasil.

Phone: $55673368-2173$

e-mail: andreott@cnpgc.embrapa.br

Received in 09/07/2011

Accepted in 03/08/2011

\section{INTRODUCTION}

The genus Trypanosoma belongs to the order Kinetoplastida and comprises parasite species that affect vertebrates of all orders (fish, amphibians, reptiles, birds and mammals) and are transmitted by various blood-sucking invertebrate vectors. One of these parasites is Trypanosoma cruzi, which is the etiologic agent of Chagas disease. Although initially a woodland enzootic, Chagas has become anthropozoonotic, mainly because the occupation of these woodland areas has reshaped transmission cycles, thereby incorporating humans and domestic animals into the epidemiological chain of T. cruzi stocks that are exchanged between sylvatic and domestic cycles ${ }^{1}$.

Trypanosoma cruzi is usually transmitted by a vector, mainly by the hematophagous Reduviidae insects, with the parasite penetrating into the host through skin lesions or mucosal or oral routes, and this last being the main way of parasite transmission to animals. The other transmissions are blood transfusions and transplacentally way ${ }^{2-4}$.

The vectors of T. cruzi, the triatomines, are members of the hemipterous family Reduviidae. Of the 138 species cataloged in $\mathrm{Brazil}^{5}$, no more than five play a direct role in the epidemiology of the parasite ${ }^{6}$ : Triatoma infestans (Klug, 1834), which is considered to be the main vector of the disease in Brazil considering it is often present in housing and is markedly anthropophilic, T. brasiliensis (Neiva, 1911), Panstrongylus megistus (Burmeister, 1835), T. pseudomaculata (Corrêa \& Espínola, 1964) and T. sordida (Stal, 1859).

The latter species is native to the cerrado, including transitional areas of Maranhão, Piaui, Bahia, Pantanal and Chaco Oriental 7 . Despite its noted bird tropism, this species can use other food sources when its environment is disturbed; as a result, it invades human homes. It is the second most common of the triatomines, with the highest number of positive individuals in the State of Mato Grosso do Sul (MS) ${ }^{8}$. 
Entomological surveys verified the existence of three major species in MS: T. brasiliensis (Neiva, 1911), P. megistus (Burmeister, 1835) and T. sordida (Stal, 1859) being infestation rates for domiciliary and peridomestics areas were significant only for T. sordida (9.3\% and $86.6 \%$, respectively), while T. brasiliensis and P. megistus showed less than $0.2 \%$ infestation for both ${ }^{8}$.

The hosts of T. cruzi are mammals, and natural infection by this parasite has been detected in the mammalian orders Didelphimorphia, Xenarthra, Chiroptera, Rodentia, Lagomorpha, Artiodactyla, Carnivora and Primates, which makes them the foci for the maintenance of the parasite in the sylvatic, peridomestic and domestic cycle. In domestic animals, the protozoan mainly infects dogs and cats, but it has also been found in pigs and goats ${ }^{2,9}$.

Furnas do Dionízio is a Quilombola community founded by Antonio Vieira, a former slave who migrated from Minas Gerais State in 1890 and settled with his family in an isolated, forested area that has always had limited contact with the surrounding communities. (The term Quilombola refers to the inhabitants of ethnically homogeneous, typically isolated rural communities of descendants of former Afro-Brazilian slaves. The term also refers to the culture of these communities). Furnas do Dionízio now numbers 96 families. Historically, basic public services have been deficient or absent in Brazilian Quilombola communities.

The major sources of income for these communities are farming (cassava, sugarcane and their derivatives) and raising livestock.
Although it practices subsistence agriculture, the community depends on government subsidies. Cultural traits dating from the earliest members have been nurtured to the present day, typically in the form of community gatherings devoted to prayers, church bazaars to celebrate the patron saints of the month of June, and the practice of the catira (a group dance).

To better understand the parasite distribution and identify risk areas in the State of Mato Grosso do Sul, this study investigated the risk of transmission of T. cruzi in the Quilombola rural community of Furnas do Dionízio, Mato Grosso do Sul, by verifying the conditions of dwellings and peridomicile structures, determining entomological indices and identifying potential mammalian hosts with molecular and parasitological tests.

\section{METHODS}

\section{Study area}

Furnas do Dionízio is a Quilombola rural community located in the county of Jaraguari, $45 \mathrm{~km}$ from Campo Grande, which is the capital City of Mato Grosso do Sul. The community covers approximately $1,031 \mathrm{ha}$, with its center at the coordinates $20^{\circ} 9^{\prime} 1.34^{\prime \prime} \mathrm{S}$ and $54^{\circ} 34^{\prime} 27.17^{\prime \prime} \mathrm{W}$ (Figure 1). Modest masonry houses predominate, usually in close proximity to wooden sties, chicken coops and corrals.

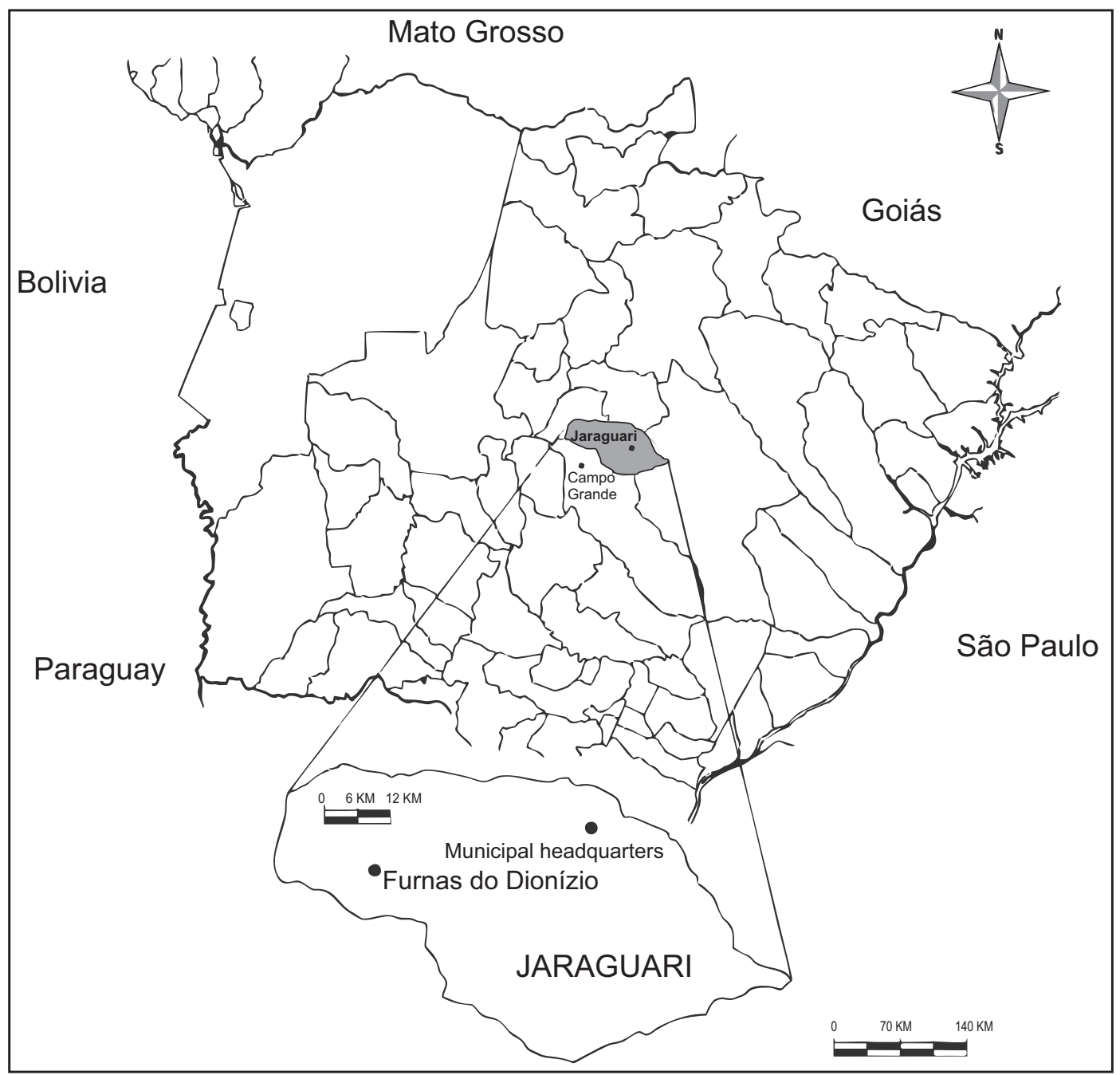

FIGURE 1 - Location of the community of Furnas do Dionízio, Jaraguari, State of Mato Grosso do Sul, Brazil. 
The capture and parasitological testing of triatomines and the calculation of entomological indices

From May to August 2009, triatomines were collected from one corral, 20 chicken coops, 20 sties and 12 barns associated with 20 households at the core of the community. This area was the most densely populated and had the most peridomicile structures and debris associated with the houses. Any area with debris, wood or tile near to or within the attached structures was investigated and classified as part of appendix closer.

Each residence and attached structure included in the triatomine research was actively searched. However, the man-hours method was not used because of the peculiarities of each environment, particularly the large volume of debris found in the annexes that required a longer and more thorough search. No dislodged products (Pirisa 5\%) were used in the study.

The sites where insects were found were classified as: L1 (sty built of masonry and purchased wooden planks), L2 (corral fenced made with purchased wood), L3 (chicken coop built of masonry and timber extracted from the local forest) and L4 (masonry house).

Insects, when found, were captured using anatomical tweezers, stored in perforated plastic bags and sent to the Laboratory of Human Parasitology at the Universidade Federal de Mato Grosso do Sul (UFMS) to be examined for natural infection by flagellates. Insects were identified according to their external morphology using graphical keys for tribes, genera and species ${ }^{10}$.

To test for parasites, each insect's abdomen was compressed to collect fecal matter in a saline solution. The material was then smeared on a slide and examined under a light microscope at $40 \times$. For each insect that tested positive for flagellates, portions of the stool sample were placed into two tubes containing solid medium NNN ( McNeal, Novy \& Nicolle) and $1 \mathrm{~mL}$ of Schneider's medium. After seven days, the samples were tested weekly for a period of four months. In total, 46 samples were obtained. The slides of the positive samples were fixed in methanol and stained with Giemsa. After examination, the specimens were individually stored in $2 \mathrm{~mL}$ Eppendorf tubes containing $70 \%$ ethyl alcohol for later molecular examination.

To determine the risk of parasite transmission by insects in the community, the entomological indices of the geographical distribution were calculated. These indices are defined by the World Health Organization (WHO) ${ }^{11}$ and include the rate of natural infection and the infestation rate:

$$
\text { Natural infection }=\frac{\text { infected triatomines }}{\text { captured triatomines }} \chi 100
$$

Infestation rate $=\frac{\text { households with triatomine }}{\text { households surveyed }} \chi 100$

A household was defined as a home and its associated structures.

\section{Mammalian examination, sample collection, and parasitological examination}

Confined animals and animals that were captured upon visitation of the ecotopes of the insect were examined in this study. For capture, 10 Tomahawk traps with dimensions of $50 \times 22.5 \times 20.5 \mathrm{~cm}$ were used and placed at least $5 \mathrm{~m}$ apart, depending on size. Near homes, the traps were placed at a distance of $10 \mathrm{~m}$ from the house as well as inside and around peridomicile structures. In each residence and attached structure, the same procedure was performed with the remaining traps in places where the insects were found by 10 days of waiting, and the bait (peanut butter and banana) was switched daily.

Blood samples from the captured mammals were collected in $5 \mathrm{~mL}$ syringes using $25 \times 0.6 \mathrm{~mm}$ BD needles (Zhejiang Ouijian Medical Apparatus, China) and then transferred to test tubes containing $5 \mathrm{~mL}$ of EDTA. No more than three hours passed between the time of collection and the laboratory tests. Samples were examined in the laboratory with a buffy coat test (three capillaries) and fresh exam (four slides).

A portion of each blood sample (six drops) was also seeded on solid medium NNN (McNeal, Novy \& Nicolle) containing $1 \mathrm{~mL}$ of Schneider's medium. After seven days, the samples were tested weekly for four months. In total, 142 samples were obtained from the collected mammal blood.

\section{Identification of protozoa}

After thin blood smear slides were prepared, fixed and stained with Giemsa, they were examined under a light microscope at $100 \times$ magnification to detect parasites and characterize their morphology ${ }^{12}$.

Molecular analysis included DNA extraction from whole animal blood and from a pool obtained from 46 cultures of the intestinal contents of triatomines that tested positive for flagellates. This pool was divided into two aliquots.

A $200 \mu \mathrm{L}$ aliquot from each blood and culture sample was transferred into a $2 \mathrm{~mL}$ Eppendorf tube, and then $400 \mu \mathrm{L}$ of lysis buffer was added, followed by homogenization for 20s in a shaker. Next, $100 \mu \mathrm{L}$ of $1 \%$ SDS was added and the solution was homogenized for $2 \mathrm{~min}$, followed by the addition of $40 \mu \mathrm{L}$ of proteinase $\mathrm{K}(20 \mathrm{mg} / \mathrm{mL})$ and a final 20s homogenization. The resulting solution was incubated in a water bath at $55^{\circ} \mathrm{C}$ for $2 \mathrm{~h}$.

A $500 \mathrm{~mL}$ volume of chloroform: isoamyl alcohol solution (24:1) was added to each sample, which was then homogenized for 20s and centrifuged at $15,700 \mathrm{~g}$ for $15 \mathrm{~min}$ in an Eppendorf 5415D microcentrifuge. The supernatant was pipetted into another $1.5 \mathrm{~mL}$ Eppendorf tube, and twice its volume in isopropyl alcohol cooled to $4^{\circ} \mathrm{C}$ was added. The resulting volume was homogenized by inverting the tube 50 times and incubated overnight at $4^{\circ} \mathrm{C}$, after which it was centrifuged at $15,700 \mathrm{~g}$ for $10 \mathrm{~min}$ at $4^{\circ} \mathrm{C}$. The supernatant was discarded and the remaining material was washed. A $500 \mathrm{~mL}$ volume of $70 \%$ ethanol at $4^{\circ} \mathrm{C}$ was added, and the sediment was centrifuged at $13,400 \mathrm{~g}$ for $5 \mathrm{~min}$ at $4^{\circ} \mathrm{C}$, after which the supernatant was discarded. This last step was repeated twice. The resulting pellet was dried in a dry bath at $60^{\circ} \mathrm{C}$ and resuspended in $100 \mathrm{~mL}$ of autoclaved ultrapure water. The samples were stored at $-20^{\circ} \mathrm{C}$.

Parasite DNA identification was based on the polymerase chain reaction (PCR), using two primers, i.e., S35 (5'-AAATAATGTACGGG(T/G)GAGATGCATGA-3') and S36 (5'-GGGTTCGATTGGGGTTGGTGT-3'), that amplify a 330-base pair (bp) fragment and anneal to the sequences of the conserved region of $\mathrm{kDNA}$ minicircles in $T$. cruzi ${ }^{13}$.

The amplification consisted of an initial denaturation at $95^{\circ} \mathrm{C}$ (10min), followed by 35 denaturation cycles at $94^{\circ} \mathrm{C}$ (30s each), annealing at $50^{\circ} \mathrm{C}(1 \mathrm{~min})$, extension at $72^{\circ} \mathrm{C}(1 \mathrm{~min})$, and a final extension (10min) in an XP thermal cycler (Bioer).

The reaction products were placed on a $2 \%$ agarose gel in TBE (Tris base, boric acid, EDTA) $1 x$ buffer and subjected to 
electrophoresis at $80 \mathrm{~V}$ and $400 \mathrm{~mA}$ for $1 \mathrm{~h} 40 \mathrm{~min}$. The gels were visualized under UV after ethidium bromide staining.

\section{Ethical considerations}

Permission for capture and examination of wild animals was granted by the Brazilian Institute for the Environment and Renewable Natural Resources (IBAMA) (permit 16611-1) and the UFMS Ethics Commission for the Use of Animals (permit 207/2009, issued 19 March 2009).

\section{RESULTS}

Figure 2 shows the households where the insects were found as well as where the mammals were captured and/or contained.

The infestation rate was $20 \%$. The highest number of captures occurred in the peridomicile structures (Table 1). These structures also sheltered livestock such as pigs, sheep and/or chickens.

Figure 2 shows that the points of capture of the insects were very irregular and isolated (except for L4).

The rate of natural infection with flagellates in triatomines was 18\% (Table 1).
In the potential vertebrate hosts (Table 2), flagellates were observed in the buffy coat tests and blood cultures of two cattle and an opossum.

Figure 3 shows the results of T. cruzi DNA amplification with S35 and S36 primers.

Two cultures from the pooled triatomine intestinal contents were positive for T. cruzi. Of 71 total blood samples from domestic, synanthropic and wild animals, two [from one opossum (3) and one pig (4)] were positive.

TABLE 1 - Triatomine capture sites and flagellate infection rates forwet smears. Furnas do Dionízio, Jaraguari, State of Mato Grosso do Sul, Brazil, 2009.

\begin{tabular}{lcrr} 
& & \multicolumn{2}{c}{ Positive } \\
\cline { 2 - 5 } Site & Number & $\mathrm{n}$ & $\%$ \\
\hline L1 & 60 & 16 & 26.7 \\
\hline L2 & 42 & 1 & 2.4 \\
\hline L3 & 22 & 6 & 27.3 \\
\hline L4 & 4 & - & \\
\hline Total & $\mathbf{1 2 8}$ & $\mathbf{2 3}$ & $\mathbf{1 8 . 0}$ \\
\hline L1: sty built of masonry and new wooden planks, L2: corral made with new wooden \\
fencing, L3: chicken coop built of masonry and timber extracted from the local forest, \\
L4: masonry house. * number of captured triatomines, $\mathbf{n}:$ number.
\end{tabular}

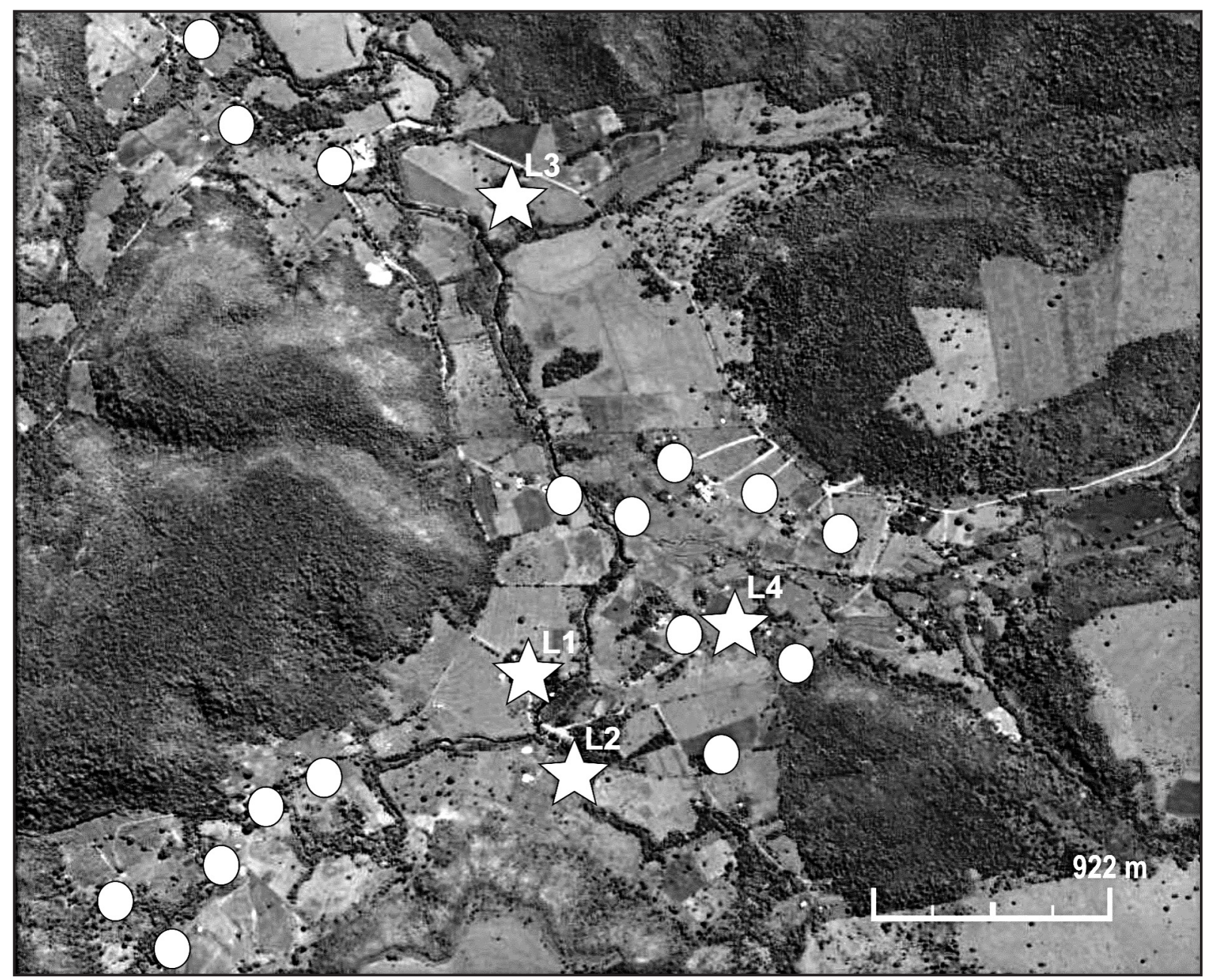

FIGURE 2 - Aerial view of the community of Furnas do Dionízio, Jaraguari, State of Mato Grosso do Sul, Brazil. Source: Google Earth (2009). $\star$ : sites where triatomines were found, $\bullet$ : sites where triatomines were not found. 
TABLE 2 - Wild, synanthropic and domestic mammals infected with Trypanosoma sp., by site and parasitological exam. Furnas do Dionízio, Jaraguari, State of Mato Grosso do Sul, Brazil, 2009.

\begin{tabular}{|c|c|c|c|c|c|}
\hline \multirow[b]{2}{*}{ Species } & \multirow{2}{*}{$\begin{array}{l}\text { Number } \\
\text { of samples }\end{array}$} & \multirow[b]{2}{*}{ Site } & \multicolumn{3}{|c|}{$\begin{array}{c}\text { Trypanosoma sp. } \\
\text { positive cases }\end{array}$} \\
\hline & & & BCE & WS & $\mathrm{BC}$ \\
\hline Didelphis albiventris & 2 & $\mathrm{~L} 1$ & - & - & 1 \\
\hline Rattus rattus & 4 & $\mathrm{~L} 2$ & - & - & - \\
\hline Dasypus novemcinctus & 1 & L1 & - & - & - \\
\hline Bos taurus & 2 & $\mathrm{~L} 1$ & 2 & - & 2 \\
\hline Canis familiaris & 1 & L1 & - & - & - \\
\hline Capra sp. & 5 & L2 & - & - & - \\
\hline Sus scrofa & 5 & $\mathrm{~L} 1$ & - & - & - \\
\hline Ovis aries & 51 & L2 & - & - & - \\
\hline Total & 71 & & 2 & - & 3 \\
\hline
\end{tabular}

L1: sty built of masonry and new wooden planks, L2: corral made with new wooden fencing.

BCE: buffy coat examination, WS: wet smears, BC: blood culture.

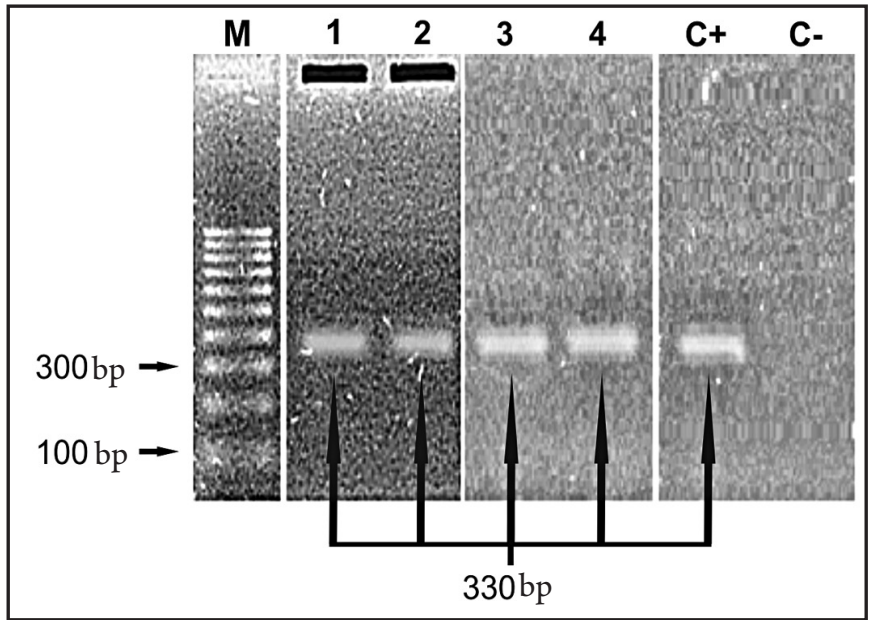

FIGURE 3 - Amplification products obtained using S35 and S36 primers for Trypanosoma cruzi.

M: marker, 1 and 2: pooled triatomine stool cultures, 3: opossum, 4: pig, $\mathbf{C}+$ : positive control, C-: negative control, bp: base pair.

\section{DISCUSSION}

The vectors of T. cruzi are often associated with mud and wood houses because these locations simulate the conditions found in their natural ecotopes. The homes in the study region were typically of this type, and some were improved in the last five years. However, with rare exceptions, no significant improvements were made in associated structures, such as pens, corrals and chicken coops. These structures are built or refurbished mostly from the timber extracted from the forest that surrounds the community, and the same wood can serve as a vehicle for triatomines.

Piles of wood and tiles were also observed near or even within the associated structures. This type of situation creates a favorable environment for insect colonization and reproduction. Although insects were not found to colonize the homes (except for L4), they were found no more than $30 \mathrm{~m}$ away from the homes, and triatomines usually suck the blood of the closest animal ${ }^{14}$. It is noteworthy that almost all of the insects infested peridomicile areas, suggesting little possibility that the houses will be colonized.

In the studied households, the only vector species found was $T$. sordida. The ability of $T$. sordida to colonize both natural and artificial ecotopes, along with its high tolerance to environmental change ${ }^{15}$, makes it an important vector in the parasite cycle and difficult to control. Despite T. sordida being considered a species that prefers to infect birds, the high rates of peridomestic infestation $(20 \%)$ and parasitic infection (18\%) suggest that surveillance is necessary because the mere coexistence with a vector increases the possibility of human infection ${ }^{16}$ besides presenting a higher rate of infection when compared with other surveys ${ }^{8,17,18}$.

Other studies showed that T. sordida is the most frequent in captures $^{17}$ - also peridomestic and domiciliary infestation reaching $86.6 \%^{8}$ and $47.7 \%{ }^{17}$, respectively - and that infection rates range from $0.2 \%^{8}$ to $2.3 \%^{18}$.

Furthermore, the insects may move and settle closer to the houses if entomological control measures are not taken. It is believed that this has not yet occurred for two reasons. First, the places where the insects were found were more isolated than the rest of the community, and L1 and L2 (which had the highest number of captures) were very close and had vegetable aisles that latched, which was not observed for other homes. However, as the rate of infestation was high, this region is at risk of becoming a new focus of vector insect colonization. Second, triatomines were found only where there were confined animals that could serve as a food source.

Because these new housing units can be built at any time, new infection foci could be found if preventive measures are not taken.

Another observation for this area is that most of the sugar cane and cassava plantations, which are the main sources of income for the community, are usually on the hillsides, which alters the vegetation cover and may facilitate the movement of triatomines closer to artificial ecotopes ${ }^{19}$. Moreover, having established a human habitation in the deforested area, it is common practice to breed livestock such as chickens, pigs, sheep and cattle to provide support for the residents and pets such as dogs and cats for protection and company. Domestic animals represent a source of food for insects and are another factor favoring the establishment of the parasite transmission cycle, as observed by Souza ${ }^{20}$, who found that $10.7 \%$ of dogs in this same area tested positive for T. cruzi.

In this work, the domestic animal that tested positive for T. cruzi was the pig (Sus scrofa). Other studies have shown that this animal hosts the parasite ${ }^{21-23}$. The results indicate a low parasitemia because it was not possible to verify the infection by parasitological testing; only the molecular testing by PCR detected the parasite DNA. This result suggests a low level of parasitemia and that the pig may be a possible source for protozoan maintenance in the Furnas do Dionízio.

Synanthropic animals were captured when the associated structures were visited, which is relevant because them are a normal part of the transmission cycle of T. $c r u z i{ }^{9}$.

Only the opossum (Didelphis albiventris) tested positive for T. cruzi (Table 2), which suggests that, along with pigs, this animal may transmit the parasite in the community because it was captured where there were colonies of triatomines. 
The concern with the opossum is that because of its ecological and behavioral characteristics, it easily acclimates to environments modified by humans when it finds suitable conditions for survival. With the construction of houses and peridomestic structures, the anthropic environment provides the opossum a niche by offering food from the accumulation of organic waste, laying hens in open spaces and poorly stored animal feed. Thesefactors lead the marsupials to invade peridomicile areas and were prevalent in the Furnas do Dionízio community.

The finding of hemoflogellates in two cattle is still under study. Although a molecular confirmation was not performed, the protozoans that were found were morphologically very similar to Trypanosoma theileri, which is a cosmopolitan parasite common in mammals of the order Artiodactyla that has been found in cattle from Mato Grosso do Sul ${ }^{24}$.

Although T. theileri is not considered to be pathogenic, it can induce chronic infections when associated with concomitant diseases ${ }^{25,26}$. New surveys, cultures and molecular biology studies of the parasite are in progress.

These results suggest that in the study region, the parasite is active in the peridomestic environment because almost all of the triatomines, as well as the infected pig and the opossum that tested positive for T. cruzi, were captured near the peridomicile structures.

These results may aid efforts to prevent parasite transmission in the community and help raise awareness in the population about the need for improvements to peridomicile structures as well as the risks involved in establishing colonies of vectors and shelters for their protozoan hosts.

\section{ACKNOWLEDGMENTS}

The authors wish to thank the Núcleo Estadual de Entomologia and Centro de Controle de Vetores do Estado de Mato Grosso do Sul, with special thanks to the civil servants Guilmara M.A. Gonçalves, João Nascimento and to Ezequiel P. Ramos for their kind attention.

\section{CONFLICT OF INTEREST}

The authors declare that there is no conflict of interest.

\section{FINANCIAL SUPPORT}

Financial support was provided by Empresa Brasileira de Pesquisa Agropecuária Gado de Corte (EMBRAPA) and Fundação de Apoio ao Desenvolvimento do Ensino, Ciência e Tecnologia do Estado de Mato Grosso do Sul (FUNDECT). A master's program grant was provided by Coordenação de Aperfeiçoamento de Pessoal de Nível Superior (CAPES).

\section{REFERENCES}

1. Tartarotti E, Azeredo-Oliveira MTV, Ceron CR. Problemática vetorial da Doença de Chagas. Arq Cienc Saude 2004; 11:44-47.

2. Rey L. Parasitologia: parasitos e doenças parasitárias do homem nos trópicos, $4^{\text {nd }}$ ed. Rio de Janeiro: Guanabara Koogan; 2008.

3. Valente SAS, Valente VC, Fraiha Neto H. Considerations on the epidemiology and transmission of Chagas disease in the Brazilian Amazon. Mem Inst Oswaldo Cruz 1999; 94:395-398.

4. Yeo M, Acosta N, Llewellyn M, Sánchez H, Adamson S, Miles GAJ, et al. Origins of Chagas disease: Didelphis species are natural hosts of T. cruzi I and armadillos hosts of T. cruzi II, including hybrids. Int J Parasitol 2005; 35: 225-233.
5. Galvão C, Carvalho R, Rocha DS, Jurberg J. A checklist of the current valid species of the subfamily Triatominae Jeannel, 1919 (Hemiptera, Reduviidae) and their geographical distribution, with nomenclatural and taxonomic notes. Zootaxa 2003; 202:1-36.

6. Vinhaes MC, Dias JCP. Doença de Chagas no Brasil. Cad Saude Publica 2000, 16:7-12

7. Forattini OP. Biogeografia, origem e distribuição da domicilização de triatomíneos no Brasil. Rev Saude Publica 2006; 40:964-998.

8. Almeida PS, Ceretti Júnior W, Obara MT, Santos HR, Barata JM. Survey of Triatominae (Hemiptera: Reduviidae) fauna in domestic environments and natural infection by Trypanosomatidae in the State of Mato Grosso do Sul. Rev Soc Bras Med Trop 2008; 41:374-380.

9. Coura JR, Dias JCP. Epidemiology, control and surveillance of Chagas disease - 100 years after its Discovery. Mem Inst Oswaldo Cruz 2009; 104:31-40.

10. Carcavallo RU, Rodrigues MEF, Galvão C, Rocha DS, Girón IG, Arocha MAO, et al. Habitats e fauna relacionada. In: Carcavallo RU, Girón IG, Jurberg J, Lent $\mathrm{H}$, editors. Atlas dos vetores da doença de Chagas nas Américas. Rio de Janeiro: Fundação Oswaldo Cruz; 1997.p. 561-600.

11. World Health Organization. Control of Chagas disease. Technical Report Series. 2005; 905:40-55.

12. Souza MA. Morphobiological characterization of Trypanosoma cruzi Chagas, 1909 and its distinction from other trypanosomes. Mem Inst Oswaldo Cruz $1999 ;$ 94:205-210

13. Sturm NR, Degrave W, Morel C, Simpson L. Sensitive detection and schizodeme classification of Trypanosoma cruzi cells by amplification of kinetoplast minicircle DNA sequences: use in diagnosis of Chagas' disease. Mol Biochem Parasitol 1989; 33:205-214

14. Wisnivesky-Colli C. Feeding patterns of triatominae in relation to transmission of american trypanosomiasis. In: Brenner RR, Stoka AM, editors. Chagas disease vectors. Boca Raton: CRC Press; 1989. p. 99-117.

15. Diotaiuti L, Loiola CF, Falcão PL, Dias JCP. The ecology of Triatoma sordida in natural environments in two different regions of the state of Minas Gerais, Brazil. Rev Inst Med Trop Sao Paulo 1993; 35:237-245.

16. Toledo MJO, KühlJB, Silva SV, Gasperi V, Araújo SM. Estudo sobre triatomíneos e reservatórios silvestres de Trypanosoma cruzi no Estado do Paraná, sul do Brasil. Resultados preliminares. Rev Soc Bras Med Trop 1997; 30:197-203.

17. De Paula MBC, Costa IN, Freitas PA, Limongi JE, Pajuaba Neto AA, Pinto RMC, et al. Occurrence of positivity for Trypanosoma cruzi in triatomine from municipalities in Southeastern Brazil, from 2002 to 2004. Rev Soc Bras Med Trop 2010; 43:9-14

18. Silveira AC, Feitosa VR, Borges R. Distribuição de triatomíneos capturados no ambiente domiciliar, no período de 1975-83, Brasil. Rev Bras Malariol Doenças Trop 1984; 36:15-312.

19. Siqueira-Batista R, Gomes AP, Rôças G, Cotta RMM, Rubião ECN, Pissinatti A. Chagas's disease and deep ecology: the anti-vectorial fight in question. Cien Saude Colet 2011; 16:677-687.

20. Souza AI. Estudo clínico da infecção natural por T. cruzi em cães residentes em uma área rural de Mato Grosso Do Sul, Brasil [Mestrado]. [Jaboticabal]: Universidade Estadual Paulista; 2007.95 p.

21. Salazar-Schettino PM, Bucio MI, Cabrera M, Bautista J. First Case of Natural Infection in Pigs. Review of Trypanosoma cruzi Reservoirs in Mexico. Mem Inst Oswaldo Cruz 1997; 92:499-502.

22. Valente VC. Potencial de domiciliação de Panstrongylus geniculatus (Latreille, 1811) (Hemiptera, Reduviidae, Triatominae) no município de Muaná, Ilha de Marajó, nordeste do Estado do Pará, Brasil. Rev Soc Bras Med Trop 1999; 32:595-597.

23. Herrera HM, Abreu AUGP, Keuroghlian A, Freitas TP, Jansen AM. The role played by sympatric collared peccary (Tayassu tajacu), white-lipped peccary (Tayassu pecari), and feral pig (Sus scrofa) as maintenance hosts for Trypanosoma evansi and Trypanosoma cruzi in a sylvatic area of Brazil. Parasitol Res 2008; 103:619-624.

24. Martins JR, Leite RC, Doyle RL. Tripanosomatides like Trypanosoma theileri in the cattle tick Boophilus microplus. Rev Bras Parasitol Vet 2008; 17:113-114.

25. Doherty ML, Windle H, Voorheis HP, Larkin H, Casey M, Clery D, et al. Clinica disease associated with Trypanosoma theileri infections in a calf in Ireland. Vet Rec 1993; 132:653-656.

26. Seif HA. Clinical trypanosomosis due to Trypanosoma theileri in a cow in Iran. Trop Anim Health Prod 1995; 27:93-94. 